\title{
The content of training program for the teaching staff working with children of the labour migrants (in the context of sustainable futures)
}

\author{
Iryna Trubavina ${ }^{1, *}$, and Anna Martyniuk ${ }^{2}$ \\ ${ }^{1}$ H. S. Skovoroda Kharkiv National Pedagogical University, Department of General Pedagogy and Pedagogy of Higher School, Kharkiv, \\ 61102, Ukraine \\ ${ }^{2}$ H. S. Skovoroda Kharkiv National Pedagogical University, Department of English language, Kharkiv, 61102, Ukraine
}

\begin{abstract}
The article deals with the ways of overcoming extreme poverty, poorness, starvation by providing quality education and well-being for labour migrants' children. These problems can be solved via teaching staff's work. The purpose of the article is to substantiate the content of the educational program for professional development of teaching staff to work with labour migrants' children and their social environment. Methods of research: theoretical analysis, synthesis, modeling, systematization, generalization. The results of the study: a set of approaches to the content of the program development; the content of the program; recommendations for its teaching. The conclusions of the study prove: labour migrants' children have problems that can be solved by interaction of teachers, social workers with the children's social environment; a new program for teachers is required; a set of scientific approaches is the basis for updating the content of the program; the educational program of pedagogical staff consists of the modules: "Problems of labour migrants' children"; "The system of GSEE work with labour migrants' children"; "Methods of GSEE work with labour migrants' children". The criterion of the effectiveness of the program and its purpose is the professional readiness of pedagogical staff to work with labor migrants' children.
\end{abstract}

\section{Introduction}

The relevance of the given article is related with:

1. The necessity to overcome such problems of our society (in the context of sustainable futures), as: poverty reduction, end hunger, good health and well-being, quality education for the labour migrants' children. Nowadays, parents in order to provide their families and children are forced to travel abroad or migrate within their country to achieve these goals for the benefit of their children, thus creating distant families which do not contribute to the best development and upbringing of their children in the family.

Visa-free regime to the countries of European Union (EU) for Ukrainian citizens, increased labour immigration of Ukrainian adults to the EU countries. The conflict in the East of Ukraine also contributed to increasing migration of families, which is proved by the number of about $1,600,000$ officially registered internally displaced persons (IDPs). Ukraine ranks $8^{\text {th }}$ in the world by the number of such persons. In this case, IDP adults leave their families in the peaceful conditions and search for the work in the Russian Federation and in the EU countries in order to provide families in Ukraine. In both cases we have children who grow up without 1 or 2 parents, and their closest surroundings are grandparents, godparents, distant relatives, neighbors and older siblings. Among the causes of mass labour immigration are poverty and poorness. Parents are forced to leave their children with relatives in order to earn money for their families. Migration can be either internal (about the country) or external (abroad). The struggle against poverty is one of the goals of the Millennium Development, and it ensures a sustainable society and its development. Therefore, the work of teaching staff at the general secondary education establishments with the labour migrants' children is aimed at overcoming poverty, assisting parents in the course of their children up-bringing, overcoming social orphanage with parents alive. As a rule, families of internally displaced person do not have homes of their own, live in difficult living conditions, including the places of compact living which we personally observed during the implementation of the EU project in Berdyansk in 2017, and where every $5^{\text {th }}$ resident was internally displaced person. We have a significant increase in the number of labour migrant children. In order to work with such children teaching staff have to be trained in a new way at the general secondary education establishments (GSEE), since they have previously been trained to work with them under peaceful conditions.

\footnotetext{
* Corresponding author: trubavina@gmail.com*
} 
2. The necessity to achieve the following Millennium Development Goals: a) overcoming extreme poverty and poorness, because adult labor migration is caused by the inability to reach a decent living standard in native country or city, so as to provide sufficient level for children upbringing; b) improving maternity protection by creating conditions for mother and a child to live together and child up-bringing in the family, maintaining the "mother-child" ties, reducing the distance between families. 3) providing the general secondary education to children via creating conditions to exercise children's rights for education, representation of their legal interests by parents in education and daily life.

3. The labour migrants' children have significant problems in socialization, development, upbringing and education, life prospects, have psychological, social, legal problems, and their immediate surroundings have no right to represent the interests of children and protect their rights, as they are not responsible for these children. It is the right and duty of their parents who are absent during a long time $[1,2,3,4]$. We have previously found out [5] that the closest social environment of a child and the teaching staff of the GSEE do not always understand the needs of such children and their problems, do not always even know about them, and cannot help to solve them, as children do not always respect teaching staff, and their functions are limited only by taking care of a child. The parents in the distance are interested only in their children's marks and what they have eaten. But unfortunately the parents are not interested in how children cope with their daily socialization problems, and how their children feel themselves.

The labour migrants' children are well organized at the general secondary educational establishments. Only the professional teacher daily sees them, and observes what is going on with a child. The teacher notices the changes that happen with the child and can quickly respond to problems as well as organize other professionals to help children. According to the order of the Ministry of Education and Science of Ukraine since 2007 all the children of labor migrants have to be registered and a special work should be conducted with them. Unfortunately, children often do not share the information that their parents have left for earnings. That is why, such children often communicate with the same children whose parents have also left for earnings in order to solve daily problems and problems of socialization [5]. In this case the role of teacher is especially great because they know about the problem. That is why there is a need in special teaching staff trained to conduct the necessary social work with labor migrants' children, as well as with their closest environment at the general secondary educational establishments. Previously the teaching staff have not been trained to such kind of work as well as to work with internally displaced person under conflict condition. All the participants of 4-days workshop within the EU project on "Creating a comprehensive system of assistance to internally displaced person from ATO zone to the community of Berdyansk" acknowledged everything above-mentioned in November 2017. All social teachers and school psychologists of the general secondary educational establishments attended that workshop. Workshops with children of labour migrants were conducted by "La Strada-Ukraine" International Women's Center in 2005-2007. Our work as a coach at workshop also proved the urgency of the problem as well as the necessity of special training for the teaching staff to such work, especially in border areas. Moreover, the lack of training courses on the problem is also vital. There is a need to train pedagogical staff to work with the immediate environment of children of labour migrants.

4. Changes in the living conditions of many children and their families as a result of the conflict in the East of Ukraine [6], which has led to family splitting, parents' mobilization, even to the death or injury of parents in the conflict. Such circumstances have also increased the children' stress due to their new roles in the family, such as: defender, helper, caregiver for young children and seniors, and other. These children lose a carelessness of a childhood and grow up early in some aspects. The teaching staff have not been previously taught to work with such war-stressed children. The psychological injuries used to be the focus of attention of psychologists and psychoneurologic dispensary. Nowadays, there are a lot of such children at secondary schools. They have to be taught and have their right for the education. So, there is a need for special training for teaching staff to work with such children, theoretical justification of the content and methods, forms of work with them.

5. The need to promptly improve the qualification of the teaching staff in the GSEE to work under new conditions of 30 hours per year (according to the Ministry's of Education of Ukraine new normative documents on the teaching staff further training in the general secondary educational establishments), instead of the previous one, which lasted for one month once in 5 years. New normative documents give the opportunity to train not only in the regional institutions of continuous education, but also in non-governmental organizations, pedagogical universities, etc. This gives an opportunity to introduce the program of the course consisting of 30 hours for pedagogical university, which has the license for further training, but the theoretical justification of its content, methods, and program modes, is required.

All above mentioned confirms that the updating of the training program content for the teaching staff working with the children of labour migrants at the general secondary educational establishments is highly required.

The theoretical analysis of the problem of further teaching staff training in order to work with labour migrants' children at the general secondary education establishments suggests that it was studied in the following areas:

1. Development of the general theoretical background for further teaching staff training $[7,8,9]$, but without taking into account the problems of labour migrants' children, the conditions of current conflict in the East of Ukraine, current working conditions at the GSEE, and the reforms in the field of education. All above-mentioned implies the need to develop the content 
of the program on the background of the theory of content education, competence- and activity-based approaches. At the same time, it is emphasized that internal displaced person's children and children of antiterrorism operation warriors are the specific subject for further teaching staff training in the current conditions.

2. Training of the certain categories of the teaching and social staff to work with children of labour migrants $[10,11]$, problems of labour migrants' children $[6,12$, 13], but without taking into consideration the dramatic increase of the problem, new working conditions of the teaching staff at the GSEE, and the need for their interaction in the interests of the children's rights support. These studies take into account the world's best experience in solving such problems. "La Strada Ukraine" is an international organization, therefore it has collected and summarized the material on the problem worldwide with the assistance of the OSCE on migration, EU countries Funds, and the Council of Europe. It was the experience which at once has presented the problem at the level of state administration, and it has been considered in scientific, organizational, and methodological aspects. The studies were conducted in the regions [5]. The Ministry of Education and Science of Ukraine issued a special edict, teaching manual on how to work with children of labour migrants [11] was published twice (2005, 2007). A special training course on Family Economics was developed and introduced to those who planned to leave their families and children in Ukraine for working abroad. In 2006 this course was the most popular in the centers of social services for family, children and youth of Ukraine, especially among people under 35 in distant and economically depressed regions of Ukraine (according to the law social services were provided only on the basis of voluntariness and honesty).

But above-mentioned studies research the details of the problems of the labour migrants' children under peaceful conditions and the ways of problem-solving created in the GSEE, which involve teachers, psychologists, cooperation with children's services, social services centers for the family, children and youth, which should also be incorporated into the content of the program. Those researches were conducted in 20052007. The living conditions in society have changed dramatically, school has changed, migration has increased and its new kinds have emerged.

3. Teacher-training course to work with parents of students [11, 13, 14], to work with distant families [15]. But there are no researches on the teaching staff training to work with the immediate environment of children while their parents are absent. In general, researches in this area emphasize the teamwork of pedagogical staff with families in interests and rights of children, which require joint activity of social teaching staff, teachers, psychologists, and educational establishment's administration on the problem.

4. There are studies on sustainable futures of education both in Ukraine and abroad. R. Anderson [16], O. E. Vysotskaya [17], I. M. Korenova [18], V. R. Ilchenko [19] conducted their researches on the theoretical background of the reforms of education for sustainable futures, its content modernization, and taking in account the world's experience of reforms in education for sustainable futures. But these works do not cover and reveal the problem of working with labour migrants' children in the context of the goals of sustainable futures, and they do not mention the problem of further teaching staff training in order to work with such children.

The purpose and objectives of the study. Considering all above mentioned, the purpose of the article is scientific substantiation of the educational program content for further teaching staff training to work with children of labour migrants. The objectives of the article are the following: 1) theoretical substantiation of the educational program content for further teaching staff training to work with children of labour migrants; 2) development of the content of the regional educational program for further teaching staff training to work with children of labour migrants; 3) development of recommendations for the teachers on such program implementation.

\section{Methodology}

We have chosen the following materials for the given study:

1. Problems of labour migrants' children and IDP children, children of anti-terrorism operation (ATO) warriors, problems of realization of the right to education of the children in the countries with conflict, which we studied and summarized on the background of the researches conducted by "La Strada - Ukraine", scientific researches of Ukrainian scientists and public persons, international reports, reports of Ukrainian state organizations and human rights activists. The methods of generalization, classification, systematization, theoretical analysis, and synthesis have been applied for their description.

2. Regulations on working with labour migrants' children issued by the Ministry of Education and Science of Ukraine, current Ukrainian legislation on education and general secondary education, social work and social services, childhood care, which allowed to determine the responsibilities and rights of teaching and social staff in the work with the labour migrants children, the possibilities of their interaction, and to model their interaction in difficult life circumstances. Methods of scientific and pedagogical research, such as concretization, modeling, synthesis, induction, and deduction have been used.

3. Family Code of Ukraine, current family policy legislation in Ukraine and gender equality, which served as a basis for defining the rights and responsibilities of parents, the people who replace them, opportunities to interact with pedagogical workers in the immediate social environment. Methods of analysis, synthesis, modeling, systematization have been applied.

4. The scientific research on improving the further teaching staff training to work with children of labour migrants and their immediate social environment [7, 12, $20]$, classification of scientific approaches to social and 
pedagogical phenomena to determine the concept of theoretical background for the development of the content of further training program $[21,22,23,24,25$, $26,27,28,29,30,31]$. We have also analyzed scientific researches as to approaches to the content of education, androgynous studies to make recommendations as to the program content, and methods and forms of its teaching. Methods of classification, systematization, comparison, theoretical analysis and synthesis have been applied.

Professional readiness of pedagogical staff to work with children of labor migrants, and motivational criterion have been chosen as the criteria for mastering the content of the new course in the context of a competence-based approach (according to the current legislation on education In Ukraine). The first criterion involves professional competence of the teaching staff in the work with labour migrants' children at the general secondary educational establishments as well as the work with social environment of labour migrants' children. Motivational criterion illustrates the attitude of teaching staff to work with children of labour migrants. The indicators of the first criterion were determined as:

1) cognitive competence: knowledge of the teaching staff about the problems of labour migrants' children at the general secondary educational establishments, social environment of children, teachers' role and functions in their work with children, the basics of interaction in the interests of children with social environment and social workers, community, knowledge of the functions of children care services, knowledge of theoretical, legal, organizational backgrounds of work with children of labour migrants, system of work with them at the general secondary educational establishments, conditions of realization of children's rights to education;

2) operational competence: the ability to identify migrants' children, identify their problems, build relationships with migrants' children, their social environment, their community, social workers; to organize work in the interests of children's rights, create conditions for the realization of their rights.

Considering our own work experience (2017-2018) in a host IDP community with social teachers and school psychologists, social workers, as well as La Strada seminars on the problem of children of labor migrants in 2005-2007, social and school psychologists, social workers, we consider that it is necessary to introduce the third motivational criterion of readiness for work with such children. The problems in the minds and motivation of the pedagogical staff that we found out during our work in recent years are the following: children of internally displaced persons had adapted earlier than adults and had less problems, than adults. Unfortunately, the pedagogical staff do not know how to deal with complicated and serious problems of such children, so they pretend that they do not notice those problems. Teachers do not want to know about the rights of migrant children because such knowledge is an extra responsibility for them. Pedagogical staff and social workers changed their attitude towards migrant children after the workshops on tolerance to internally displaced persons (due to the project in Berdyansk). Teachers expressed such ideas while summarizing the results of the workshops: they understood what the children have come through and how they do live now, so they treat them better, want to help them to return their childhood and make their adaptation easier. The attitude of pedagogical staff to the rights of the child as a basis for interaction in the interests of the children and their rights was changed, after the workshops of "La Strada". Now, that is stated in the concept of the New Ukrainian School. Therefore, the such a criterion for an advanced training course is considered compulsory along with professional cognitive and operational competences. We should underline that the proposed workshop program is brand new and does not involve the previous two programmes. It is concerned with the current problems of children. The experience of their development as well as the implementation of their results have been taken into account for the development of a new program for pedagogical staff at the general secondary educational establishments regardless of the region.

We have considered the criteria and indicators of competence for work with children of labor migrants at 3 levels - high, medium, low. High level characterizes completeness of knowledge and skills development, while medium level - incomplete knowledge and partially developed skills, and low level shows lack of knowledge and skills to work with children of migrant workers.

Motivational criterion of readiness we determined by the attitude of pedagogical staff to the children of labour migrants: positive, neutral, negative. Positive attitude is characterized by the wish to help the child and to treat him or her as a subject of interaction with pedagogical staff at the general secondary educational establishments. The neutral attitude is characterized by treating a child as an object of pedagogical influence. The negative attitude is characterized by treating a child as a victim. The basis for the selection of such indicators is child-centrism and the rights of the child. The attitude itself determines the warmth of the relationship with the child, while the motives indicate the cause for the work. In our case, work is a job and it must be done. But this work can be done with different attitudes. That is why attitude is the main indicator of motivational criterion of the readiness of pedagogical staff to work with children of labour migrants at the general secondary educational establishments.

In order to evaluate the effectiveness of mastering the content of the workshop on the problem, we developed a self-assessment questionnaire for the teaching staff. Let us consider its contents.

$$
\text { Dear participants! }
$$

Thank you for taking the time to participate in this study. The survey is conducted in order to identify the impact of the workshop on your professional competence to carry out psychological, socialpedagogical and educational work with the children of labour migrant at the modern general secondary educational establishments.
1. Please
name
your
position at
work 
2. Do you have experience of working with migrant children? (choose one of the answers): a) yes; b) no; c) some.

3. Are you familiar with the problems of labour migrant's children? (choose one of the answers): a) yes; b) no; c) a little.

4. Do you know how to conduct educational work with the children of labour migrants? (choose one of the answers): a) yes; b) no; c) on certain issues.

5. Do you know how a social teacher works with children from labour migrant families? (choose one of the answers): a) yes; b) no; c) a little.

6 . Do you know what kind of work a psychologist does with the children of labour migrant?

7. Do you know about such methods of developing the tolerance and culture as living libraries, living books, tolerance camps, interactive educational classes, etc.: a) yes; b) no; c) a little.

8. Do you know the theoretical background of work with children from labour migrant families? (choose one of the answers): a) yes; b) no; c) a little.

9. Do you know what is a recovering practice at school? (choose one of the answers): a) yes; b) no; c) a little.

10. Do you know how to mediate at the general secondary educational establishments? (choose one of the answers): a) yes; b) no; c) a little.

11. Do you know any method of working with parents and the social environment of labour migrants' children (choose one of the answers): a) yes; b) no.

12. Do you know how to assess child's needs? (choose one of the answers): a) yes; b) no; c) a little.

13. What is your attitude towards labour migrants' children? (choose one of the answers): a) as to victims; b) as to the subjects of pedagogical and psychological work; c) as to the subjects of pedagogical influence.

14. Do you know about the impact of military conflict on children's behavior and psyche? a) yes; b) no; c) a little.

15. Can you solve the problems with children at the higher educational establishments? a) yes; b) no; c) sometimes.

16. Do you know about the possibilities of social services in overcoming the problems of children from labour migrant families? A) yes: b) no; c) a little.

17. Do you know how to overcome stereotypes about internally displaced persons' children and labour migrants' children at school environment? A) yes: b) no; c) a little.

This questionnaire was conducted among 25 correspondence students of the Institute of Postgraduate Education (IPE) of H. S. Skovoroda Kharkiv National Pedagogical University (H. S. Skovoroda KhNPU), who studied the Master's program "Management of the educational institution". A cluster sample was applied. The questionnaire was conducted in May 2019.

We found out in the course of the study that while developing an educational program for the further training of the teaching staff the following issues should be taken into account:

a) a set of scientific approaches, because none of scientific approaches solves the problem, as it should be considered in social, pedagogical, legal, and psychological aspects;

b) the theoretical background of the program content are scientific approaches at different levels, that is why the problem is not only pedagogical. It requires knowledge from different fields of knowledge and interaction of pedagogical and social staff at the GSEE and community;

c) taking into account the ways of problem-solving the set of approaches to develop the content of the program should involve the following scientific approaches:

- philosophical: child-centered, epistemological, pragmatic, family-centered.

- general scientific: systemic, synergetic, critical, political, activity-based, axiological, historical.

- specifically scientific: legal (human rights theory, human development theory, family law, administrative law, social security law, civil law, approaches to human rights protection); social work (crisis intervention, help for self-assistance, resource-based, diagnostic, clientoriented and problem-oriented approaches); social pedagogy (theories of socialization, environmental, social and educational, personal, family-centered approaches to social and pedagogical activity); psychological (genetic, structural-functional, dynamic directions of psychological theories); public administration (regional, institutional and state approaches).

- pedagogical approaches: androgynous, competencebased, personal-oriented approaches, pedagogical support, pedagogy of non-violence, friendly approach, theories of educational content.

In order to substantiate the content of the program of the new course and to confirm its relevance, we conducted a survey of pedagogical staff on the developed questionnaire. The results of the questionnaire survey of pedagogical staff of the GSEE are shown in Table 1.

Table 1. Level of professional readiness criteria (25 people).

\begin{tabular}{|c|c|c|c|}
\hline & $\begin{array}{c}\text { Cognitive } \\
\text { criterion }\end{array}$ & $\begin{array}{c}\text { Operational } \\
\text { criterion }\end{array}$ & $\begin{array}{c}\text { Motivational } \\
\text { criterion }\end{array}$ \\
\hline High level & $1 / 4 \%$ & 0 & $5 / 20 \%$ \\
\hline Medium level & $13 / 52 \%$ & $9 / 36 \%$ & $12 / 48 \%$ \\
\hline Low level & $11 / 44 \%$ & $16 / 64 \%$ & $8 / 32 \%$ \\
\hline
\end{tabular}

These data confirm that in general the level of professional readiness of pedagogical workers to work with children of labor migrants at the GSEE is low, in particular an average level of teacher's attitude is observed according to the motivational criterion (emphasis on the rights of the child and child-centrism). As to cognitive criterion, there is almost no complete knowledge as to the work with children of labour migrant and their social environment. Operational criterion proves that more than half of the trainees do not have working skills. Such results prove the relevance of the development of the above-mentioned course for advanced training, the correctness of our considerations on the problem.

All these approaches have allowed us to develop the content of a regional educational program to improve the 
teaching staff training to their work with the labour migrants' children and their immediate social environment. We have used the methods of synthesis, generalization, concretization, and modeling. So, let us reveal the programm contents.

In the explanatory letter it is stated that the course is aimed to assist the teaching staff at the GSEE in organizing better conditions for exercising the right to education for labour migrants' children. It characterizes the concept of "labour migrants' children", their categories and problems of each of them, common and different in the problems and needs of children. The concept of parental responsibility, parenthood, rights and responsibilities of parents, the concept of the closest social environment of children and its ability to represent and protect the rights of children, make decisions about children are also disclosed. The experience of education, upbringing and socialization of labour migrants' children at the GSEE in Ukraine as well as abroad is generalized. The course reveals the basics of the interaction of the teaching staff of the GSEE with one another, the interaction of the GSEE with community institutions in the interests of children, with the closest social environment of children. The rights and obligations of the parties in creating the conditions for the realization of the rights of children, their successful socialization, education, upbringing and development are identified. The ways of solving the problem in the GSEE through schools, child-friendly schools, school socialpsychological-pedagogical services, pedagogy of nonviolence, school services of understanding, work of class leaders. The necessity of mastering this training course for the teaching staff "The work of the general secondary education establishments teaching staff with the children of labour migrants and their closest social environment" is caused by the need to develop the professional competences of teachers to work with labour migrants' children and their closest social workers.

The purpose of the teaching staff further training in the GSEE (teachers, social teaching staff, psychologists) is developing their professional competence; deepening knowledge about the education, socialization and development of labour migrants' children in the new environment; getting acquainted with the modern ways of exercising their rights in the GSEE, interacting with their immediate social environment for the benefit of children. The objectives of the course "The work of the general secondary education establishments teaching staff with labour migrants' children and their closest social environment" are defined as follows: to increase their professional competence, to form the new pedagogical thinking, teaching staff readiness to create various social, pedagogical, legal conditions of the rights for the education of labour migrants' children, including through interaction with their social environment.

The program consists of three modules: "Problems of labour migrants" children", "System of work in the GSEE with labour migrants' children", "Teaching methodology of work at the GSEE with labour migrants' children". The educational-thematic plan of the program is designed for 30 hours of the full-time distance learning: 10 hours - full-time education; 20 hours - selfstudy (correspondence course).

The topics of the module "Problems of labour migrants' children" are designed for assimilation of complicated problems of labour migrants' children and their families by the teaching staff: psychological, pedagogical, social-pedagogical, social, legal, medical, economic, communication between them; typical problems of labour migrants' children of different ages, depending on the reasons of parental migration: developmental problems, problems of socialization, problems of education, problems of communication and behavior, formulation of life prospects and selfdetermination, problems of education, formation of model of family life. Understanding the immediate social environment of the child, its structure, opportunities to communicate with him. It is important to form teaching staff with an empathic attitude towards migrants' children, positive motivation to work with their social environment, treat parents of children as those who fulfill their parental responsibilities as loving, strengthen family ties, parent-child relationships.

The second module "System of work in the general secondary educational establishments with labour migrants' children", the normative and theoretical framework of teaching staff interaction with the children, their families, immediate social environment, the ideology of such interaction (the rights of the child, their protection and creation of conditions for realization of rights, crisis intervention, attachment theory, etc.) should be disclosed.

The module "Teaching methodology of work in the general secondary educational establishments with labour migrants' children" reveals the methodology of work of the school psychologist, social teacher, class leader with labour migrants' children. The role of school administration in work with such children, multidisciplinary school team in work with them, specialized school services, which are friendly with children, school services of understanding, pedagogy of nonviolence, features of patriotic and national education, orientation with such children.

So, lets discover the content of the proposed educational program "The work of the general secondary education establishments teaching staff with labour migrants' children and their closest social environment" in modules and topics:

Module 1. "Problems of labour migrants' children".

Topic 1.1. Problems of labour migrants' children.

Problems of labour migrants' children: psychological, legal, pedagogical, social, social and pedagogical, medical, economic, connection between them. Typical problems of development, education, age problems, problems of socialization of labour migrants' children, problems of communication, behavior, formation of model of family life and upbringing, life prospects, etc.

Topic 1.2. The concept of the immediate family environment of labour migrants' children.

Parents of children: their rights and responsibilities, responsibility for children. The closest social environment of labour migrants' children, their 
composition, role in child care and upbringing, opportunities and rights, connection with them.

Topic 1.3. The labour migrants' child as an object and subject of pedagogical activity.

The labour migrants' children at the general secondary educational establishments. Problems of their detection in the GSEE and formation of trust in pedagogical workers. The role of social educator, classroom leader, classmate, school psychologist, GSEE administration in working with such children, their opportunities and job responsibilities

Module 2. "The system of work with labour migrants' children at the GSEE".

Topic 2.1. Legal framework for the work of teaching staff with the labour migrants' children at the GSEE.

Legislation of child protection, education, secondary education, family code of Ukraine, Declaration of School Safety. The subjects and objects of children's rights protection, the right of the child to education. Parents' responsibility for children. Rights and opportunities for communication with the child's immediate social environment.

Topic 2.2. Theoretical foundations of the teaching staff work with the labour migrants' children at the GSEE.

Theory of human rights and human development, child-centrism, family- centrism, systematic work with labour migrants' children attachment theory, family development theory, resource approach, environmental approach, participatory theory, community work.

Topic 2.3. The system of work with labour migrants' children at the GSEE.

The Ministry's of education orders about work with labour migrants' children at the GSEE. Registration children into school records and systematic work with them by social educators and school psychologists, administration.

Module 3. "Methods of work with labour migrants' children at the GSEE".

Topic 3.1. Work with the child's immediate social environment and the possibility of indirect work with parents of children.

The multidisciplinary team work with the labour migrants' children and their immediate social environment. Rights and responsibilities of pedagogical and social workers, interaction of community services about children's rights.

Topic 3.2. Organization of the work with labour migrants' children at the GSEE.

School social psychological and pedagogical service. Understanding Service. Pedagogy of non-violence. Child-friendly schools. Countering bulling against labour migrants' children.

Topic 3.3. Creating conditions for realization the right for education of labour migrants' children at the GSEE.

Features of patriotic, national and labor education of labour migrants' children. Assisting children in vocational guidance. Assistance in learning and stimulation, motivation of children to education. Economic education of children. "Self-help assistance" in working with children of labour migrants' children to determine life prospects and their realization.

Taking into account the age and the level of teaching staff training, we recommend to use the following teaching methods: 1) the nature of cognitive activity: explanatory, illustrative, reproductive, problematic presentation, partially search, research; 2) by sources of knowledge: information, illustration, demonstration, discussions, learning from experiences, situations, situation analysis, brainstorming. It is advisable to use such forms of study as work in microgroups, practical classes, training classes.

\section{The results of the research}

The structure of the course "The work of the general secondary education establishments teaching staff with the labour migrants' children and their closest social environment" is shown in the table 2.

Table 2. The structure of the course "The work of the general secondary education establishments teaching staff with the labour migrants' children and their closest social environment".

\begin{tabular}{|c|c|c|c|}
\hline \multirow[t]{2}{*}{ Module themes } & \multicolumn{2}{|c|}{\begin{tabular}{|c|}
$\begin{array}{c}\text { Classroom } \\
\text { hours }\end{array}$ \\
\end{tabular}} & $\begin{array}{c}\text { Individual } \\
\text { work }\end{array}$ \\
\hline & lecture & torials & \\
\hline \multicolumn{4}{|c|}{ Module 1. Problems of labour migrants' children } \\
\hline $\begin{array}{c}\text { Topic 1.1. Problems of labour } \\
\text { migrants' children }\end{array}$ & 1 & - & - \\
\hline $\begin{array}{l}\text { Topic } 1.2 \text {. The concept of the } \\
\text { immediate family environment } \\
\text { of labour migrants' children }\end{array}$ & 1 & - & 4 \\
\hline $\begin{array}{c}\text { Topic } 1.3 \text {. The labour migrants' } \\
\text { child as an object and subject of } \\
\text { pedagogical activity. }\end{array}$ & 1 & 1 & 2 \\
\hline \multicolumn{4}{|c|}{$\begin{array}{l}\text { Module 2. The system of work with labour migrants' children } \\
\text { at the GSEE }\end{array}$} \\
\hline $\begin{array}{l}\text { Topic 2.1. Legal framework for } \\
\text { the work of teaching staff with } \\
\text { the labour migrants' children at } \\
\text { the GSEE }\end{array}$ & 0,5 & - & 2 \\
\hline $\begin{array}{c}\text { Topic } 2.2 . \text { Theoretical } \\
\text { background of the teaching staff } \\
\text { work with the labour migrants' } \\
\text { children at the GSEE }\end{array}$ & 1 & - & 4 \\
\hline $\begin{array}{c}\text { Topic 2.3. The system of work } \\
\text { with labour migrants' children at } \\
\text { the GSEE }\end{array}$ & 0,5 & 1 & - \\
\hline \multicolumn{4}{|c|}{$\begin{array}{c}\text { Module 3. Methods of work with labour migrants' children at } \\
\text { the GSEE }\end{array}$} \\
\hline $\begin{array}{l}\text { Topic } 3.1 \text { Work with the child's } \\
\text { immediate social environment } \\
\text { and the possibility of indirect } \\
\text { work with parents of children }\end{array}$ & 0,5 & - & 2 \\
\hline $\begin{array}{c}\text { Topic 3.2. Organization of the } \\
\text { work with labour migrants' } \\
\text { children at the GSEE }\end{array}$ & 1 & 1 & 4 \\
\hline $\begin{array}{l}\text { Topic 3.3. Creating conditions } \\
\text { for realization the right for } \\
\text { education of labour migrants' } \\
\text { children at the GSEE }\end{array}$ & 0,5 & - & 4 \\
\hline Total & 7 & 3 & 20 \\
\hline
\end{tabular}


Taking into account the trainees' age and level of preparation, we recommend to use the following teaching methods: 1) by the nature of cognitive activity: explanatory, illustrative, reproductive, problematic presentation, partially searching, researching; 2) by the sources of knowledge: informative, illustrating, demonstrating, discussing, learning from experiences, situational, situation analysis, brainstorming. It is reasonable to use such forms of study as work in microgroups, practical classes, and training sessions.

From the results of the study presented in the article it is obvious that the teaching staff at the GSEE do not work in a multidisciplinary team today, this idea is promoted only at the level of the children's ombudsman of Ukraine, each educator in his/her position is a leader and seeks through inherent teacher-training humanism to solve all the problems of children themselves, without even having the necessary competences, only because of his/her natural kindness and sincere desire to help children. It usually causes professional burnout, frustration, overwork, stress and even illness. Therefore, teaching to teamwork at the GSEE and community on the background of regulatory documents, theoretical foundations, interaction between teaching staff and their integration into a certain structure would better help children, teach how to solve their problems comprehensively and systematically, save teachers' resources. Besides, knowledge of the theoretical background of working with the families of labour migrants' children allows them to provide targeted assistance to children and their immediate social environment, rather than simply to show kindness where professional help is needed. So, the proposed educational course will be helpful for solving the problems of labour migrants' children and their immediate environment, as well as dysfunctional and distant families, incomplete families, foster families, and social orphans.

\section{Conclusion}

It was proved that the problem of the teaching staff work with labour migrants' children at the general secondary educational establishments is urgent in order to overcome poorness and poverty in Ukraine. The problem has new features in connection with the military conflict in Ukraine, visa-free regime with the European Union for Ukrainians and is solved by implementation of work with labour migants' children and their close environment by improving the content of teachers' further training program. It was discovered that the aim of teaching staff' training is the professional readiness to work with children of labour migrants at the GSEE. It is characterized by cognitive, operational, motivational criteria. The level of development is characterized as high, medium, and low. It was distinguished that the level of teachers' readiness to work with labour migrants' children is typically low according to cognitive and operational criteria, and medium according to motivational criterion. A set of the following scientific approaches at different levels for updating the content of the regional educational program for teaching staff further training for their work at multidisciplinary team was developed: 1) philosophical; 2) general scientific; 3) specifically scientific; 4) pedagogical. On this basis we have developed a new educational program to improve the skills of the teaching staff for work with the labour migrants' children and their social environment which consist of 3 modules ("Problems of labour migrants' children", "The system of work with labour migrants' children at the GSEE", "Methods of work with labour migrants' children at the GSEE"). The program includes 30 hours of training, and recommendations on the program's teaching, which correspond to its purposes, methods and appropriate forms for adults training.

The prospects for further research are in the field of testing and experimental verification of the programs.

\section{References}

1. S. M. Fursa, O.V. Datsko, Psykholohichni problemy ditey iz simey mihrantiv (Psychological problems of children from migrant families). Molodyy vchenyy 11, 1795-1797 (2016),

https://moluch.ru/archive/115/30744/. Accessed 11 Sep 2019

2. K. Kovyazina, Shchodo vdoskonalennya sotsial'noho zakhystu ditey trudovykh mihrantiv". Analitychna zapyska (On improving the social protection of children of migrant workers. Analytical note) (Natsional'nyy instytut stratehichnykh doslidzhen', 2012), https://niss.gov.ua/doslidzhennya/socialnapolitika/schodo-vdoskonalennya-socialnogozakhistu-ditey-trudovikh-migrantiv. Accessed 25 October 2019

3. V. Rul, Zhyttyevi trudnoshchi ditey trudovykh mihrantiv $\mathrm{v}$ umovakh stanovlennya ukrayins'koho demokratychnoho suspil'stva (Life difficulties of children of labor migrants in the conditions of establishing the ukrainian democratic society), in Naukovyy visnyk Uzhhorods'koho universytetu seriya: politolohiya, sotsiolohiya, filosofiya 13, 214 217 (2009)

4. M. Shevtsova, Yevrosyroty: z chym stykayut'sya dity ukrayins'kykh trudovykh mihrantiv (Euroorphans: What do the children of Ukrainian migrant workers face with). (Ukrayins'ka Pravda, 2017), https://life.pravda.com.ua/society/2017/05/4/224005 1. Accessed 10 Dec 2019

5. Yu.M. Galustyan, I.A. Schwab, T.O. Doroshok, K.B. Levchenko, I.M. Trubavina, Problemy ditei trudovykh mihrantiv: analiz sytuatsii (The Problems of migrant workers' children: situation analysis). (Mizhnarodnyy zhinochyy pravozakhysnyy tsentr "La Strada-Ukrayina", Ukrayins'kyy instytut sotsial'nykh doslidzhen' im. O. Yaremenka, Kirovohrads'kyy yurydychnyy instytut Kharkivs'koho natsional'noho universytetu vnutrishnikh sprav, Kyiv, 2006)

6. I. M. Trubavina, Problemy vnutrishno peremishchenykh osib $\mathrm{V}$ Ukraini yak osnova 
sotsialno-pedahohichnoy roboty $\mathrm{z}$ nymy (The problems of internally displaced persons in Ukraine as a basis for social and pedagogical work with them). Pedahohichny nauky: teoriya, istoriya, innovatsiini tekhnolohiy 8 (52), 434-446 (2015)

7. T.S. Kazymova, Teoreticheskie osnovy protsessa povyshenyia kvalifikatsii prepodavatelia: eho sushchnost, strukturoobrazuiushchie komponenty hotovnosti i pryntsypy (The theoretical grounds of the process of improving a teacher's qualification: its essence, structure-forming components of readiness and principles). Sovremennye problemy nauki i obrazovaniia 6 (2016), http://www.scienceeducation.ru/ru/article/view?id=25929. Accessed 20 Dec 2019

8. V. Suprun, Teoretyko-metodolhichni zasady pidvyshchennia kvalifikatsii pedahohichnykh pratsivnykiv u systemi profesiinoi osvity Ukrainy (Theoretical and methodological foundations of improving pedagogical workers' qualification in the system of professional education of Ukraine). Pisliadyplomna osvita v Ukraini 1, 1-22 (2017)

9. T. Sorochan, Pisliadyplomna pedahohichna osvita: mozhlyvi vidpovidi na vyklyky modernizatsii (Postgraduate Teacher Education: Possible Answers to Modernization Challenges). Pisliadyplomna osvita v Ukraini 2(37), 9-12 (2015)

10. V.M. Pihida, Sotsialno-pedahohichna diialnist $\mathrm{z}$ ditmy trudovykh mihrantiv (Social and pedagogical activities done with migrant workers' children). Naukovyi visnyk Uzhhorodskoho natsionalnoho universytetu. Seriia Pedahohika, sotsialna robota 1, 157-160 (2011)

11. K.B. Levchenko, I.M. Trubavina, I.I. Tsushko (eds.) Sotsialno-pedahohichna ta psykholohichna robota $z$ ditmy trudovykh mihrantiv (Socio-pedagogical and psychological work with migrant workers' children). (Kyiv, 2007)

12. C. Huber, A. Gerullis, M. Gebhardt, S. Schwab, The impact of social referencing on social acceptance of children with disabilities and migrant background: an experimental study in primary school settings. European Journal of Special Needs Education 33, 269-285 (2018). doi:10.1080/08856257.2018.1424778

13. N.V. Hordiienko, Suchasna sim'ia trudovykh mihrantiv yak ob'iekt sotsialno-pedahohichnoi roboty v Ukraini (A modern migrant workers' family as an object of social and pedagogical work in Ukraine). Pedahohichni nauky 3(74), 132-136 (2016)

14. E.S. Puffer, J. Annan, A.L. Sim, C. Salhi, T.S. Betancourt, The impact of a family skills training intervention among Burmese migrant families in Thailand: a randomized controlled trial. PloS one 12(3), 9 (2017). doi:10.1371/journal.pone.0172611

15. N.I. Kubiak, D.Ya. Romaniuk, Sotsialnopedahohichna robota $\mathrm{Z}$ dystantnymy simiamy
(Social and pedagogical work with distant families). Sotsialno-humanitarnyi visnyk 26-27, 62-63 (2019)

16. R. Anderson, The Content Reform of Education for Sustainable Development, in Rural Environment. Education. Personality (REEP), Proceedings of the International Scientific Conference, Jelgava, 2015, vol. 8, pp. 75-81, https://lufb.llu.lv/conference/REEP/2015/LatviaUniv-Agricult-REEP-2015proceedings.pdf. Accessed 23 Aug 2019

17. O.E. Vysotskaya, Osvita dlya staloho rozvytku (Education for Sustainable Development). (Royal Print, Dnepropetrovsk, 2011)

18. I.M. Koreneva, Fenomen "osvita dlya staloho rozvytku": sutnist' ta suchasni osoblyvosti kontseptu (Phenomenon "education for sustainable development": the essence and modern features of the concept). Ukrayins'kyy pedahohichnyy zhurnal 2, 113-118 (2018)

19. V.R. Ilchenko, Modernizatsiya zmistu zahal'noyi seredn'oyi osvity Ukrayiny na zasadakh osvity dlya staloho rozvytku: nacherk proektu eksperymental'noho doslidzhennya (Modernization of the of general secondary education of Ukraine content on the principles of education for sustainable development: an outline of the experimental research project). Postmetodyka 5(102), 16-17 (2011)

20. H. Dmytrenko, Pisliadyplomna osvita yak realizator liudynotsentrychnoi modernizatsii natsionalnoi systemy osvity (Postgraduate education as an implementor of human-centric modernization of the national education system). Pisliadyplomna osvita $\mathrm{V}$ Ukraini 2(37), 3-9 (2015)

21. Y. A. Lypskyi, Sotsyalnaia pedahohyka: metodolohycheskyi analyz (Social pedagogy: methodological analysis). (Tvorcheskyi Tsentr Sfera, Moscow, 2004)

22. E.Ya. Orekhova, A.I. Orekhov, Novyye metodologicheskiye podkhody $\mathrm{v}$ pedagogicheskikh issledovaniyakh (New methodological approaches in pedagogical research). Sovremennyye problemy nauki i obrazovaniya 1(1), (2015), http://www.science-

education.ru/ru/article/view? $\mathrm{id}=18114$. Accessed 25 Oct 2019

23. L. Wenquan, Dissertation, Vostochno-sibirskaya gosudarstvennaya akademiya, 2012

24. I. Kukuev, Dissertation, Yuzhnyy federal'nyy universitet, 2010

25. O. V. Kitikar', Nauchnyye podkhody k klassifikatsii ponyatiy $\mathrm{V}$ pedagogicheskoy nauke (Scientific approaches to classification of concepts in pedagogical science). Problemy sovremennogo pedagogicheskogo obrazovaniya 55-4, 244-251 (2017)

26. S.O. Sysoieva, T.E. Krystopchuk, Metodolohiya naukovo-pedahohichnykh doslidzhen' (Methodology 
of scientific and pedagogical research). (Volyns'ki oberehy, Rivne, 2013)

27. V.I. Zagvyazinsky, R. Atakhanov, Metodologiya $i$ metody psikhologopedagogicheskogo issledovaniya (Methodology and methods of psycho-pedagogical research). (Izdatel'skiy tsentr Akademiya, Moscow, 2007)

28. L. Gavrylova, Naukovo-metodolohichni pidkhody do analizu profesiynoyi kompetentsiyi maybutnikh uchyteliv pochatkovykh klasiv (Scientific and methodological approaches to the analysis of professional competence of future primary school teachers). Profesionalizm pedagoga, teoretychni i metodychni aspekty 2 (2015), http://pptma.dn.ua/files/2015/2/3.gavrilova.7-17.pdf. Accessed 25 Oct 2019

29. S.M. Khatuntseva, Metodolohichni pidkhody formuvannya u maybutnikh uchyteliv hotovnosti do samovdoskonalennya $\mathrm{v}$ protsesi indyvidualizatsiyi profesiynoyi pidhotovky (Methodological approaches for formation in future teachers' ready for self-perfection in the process of individualization of professional training). Pedahohika ta psykholohiya $\quad \mathbf{5 8}$ (2017). doi:10.5281/zenodo. 11170345

30. O.A. Dubasenyuk, Kompetentnisnyy pidkhid u profesiyniy pidhotovtsi vchytelya (Kompetency approach in teacher training), in Formuvannya estetychnoyi kompetentnosti osobystosti zasobamy narodoznavstva, ed. by O.S. Berezyuk, L.O. Hlazunova (Zhytomyr, 2010)

31. K. Binitska, Kontseptual'ni pidkhody do modeley profesiynoyi pidhotovky vchytelya pochatkovoyi osvity u krayinakh Yevropeyskoho Soyuzu (Conceptual approaches to models of vocational training for primary education teachers in EU countries). Studia Zarządzania i Finansów Wyższej Szkoły Bankowej w Poznaniu 13, 135-142 (2017) 